University of Nebraska - Lincoln

DigitalCommons@University of Nebraska - Lincoln

U.S. Department of Veterans Affairs Staff

Publications

U.S. Department of Veterans Affairs

2004

\title{
Hepatocellular Carcinoma in the Woodchuck Model of Hepatitis B Virus Infection
}

Bud C. Tennant

Cornell University, bct3@cornell.edu

Ilia A. Toshkov

Cornell University

Simon F. Peek

University of Wisconsin-Madison

James R. Jacob

Cornell University, jij2@cornell.edu

Stephan Menne

Cornell University, sm119@cornell.edu

See next page for additional authors

Follow this and additional works at: https://digitalcommons.unl.edu/veterans

Tennant, Bud C.; Toshkov, llia A.; Peek, Simon F.; Jacob, James R.; Menne, Stephan; Hornbuckle, William E.; Schinazi, Raymond D.; Korba, Brent E.; Cote, Paul J.; and Gerin, John L., "Hepatocellular Carcinoma in the Woodchuck Model of Hepatitis B Virus Infection" (2004). U.S. Department of Veterans Affairs Staff Publications. 79.

https://digitalcommons.unl.edu/veterans/79

This Article is brought to you for free and open access by the U.S. Department of Veterans Affairs at DigitalCommons@University of Nebraska - Lincoln. It has been accepted for inclusion in U.S. Department of Veterans Affairs Staff Publications by an authorized administrator of DigitalCommons@University of Nebraska - Lincoln. 


\section{Authors}

Bud C. Tennant, llia A. Toshkov, Simon F. Peek, James R. Jacob, Stephan Menne, William E. Hornbuckle, Raymond D. Schinazi, Brent E. Korba, Paul J. Cote, and John L. Gerin 


\title{
Hepatocellular Carcinoma in the Woodchuck Model of Hepatitis B Virus Infection
}

\author{
BUD C. TENNANT,* ILIA A. TOSHKOV,* SIMON F. PEEK, ${ }^{\ddagger}$ JAMES R. JACOB,* STEPHAN MENNE,* \\ WILLIAM E. HORNBUCKLE,* RAYMOND D. SCHINAZI,§ BRENT E. KORBA," PAUL J. COTE," and \\ JOHN L. GERIN" \\ *Gastrointestinal Unit, Department of Clinical Sciences, New York State College of Veterinary Medicine, Cornell University, Ithaca, New York; \\ ${ }^{\ddagger}$ Department of Medical Sciences, School of Veterinary Medicine, University of Wisconsin-Madison, Madison, Wisconsin; ${ }^{\circledR}$ Department of \\ Veterans Affairs, Emory School of Medicine, Decatur, Georgia; and "Division of Molecular Virology and Immunology, Georgetown University \\ Medical School, Rockville, Maryland
}

The Eastern woodchuck (Marmota monax) harbors a DNA virus (Woodchuck hepatitis virus [WHV]) that is similar in structure and replicative life cycle to the human hepatitis B virus (HBV). Like HBV, WHV infects the liver and can cause acute and chronic hepatitis. Furthermore, chronic WHV infection in woodchucks usually leads to development of hepatocellular carcinoma (HCC) within the first 2-4 years of life. The woodchuck model has been important in the preclinical evaluation of safety and efficacy of the antiviral drugs now in use for treatment of HBV infection and continues to serve as an important, predictive model for innovative forms of therapy of hepatitis B using antiviral nucleosides and immune response modifiers alone or in combination. Almost all woodchucks that become chronic WHV carriers after experimental neonatal inoculation develop HCC with a median HCC-free survival of 24 months and a median life expectancy of 30-32 months. The woodchuck model of viralinduced HCC has been used effectively for the development of new imaging agents for enhancement of detection of hepatic neoplasms by ultrasound and magnetic resonance imaging. The chemoprevention of HCC using long-term antiviral nucleoside therapy has been shown in the woodchuck, and "proof of principal" has been established for some of the innovative, molecular methods for treatment of HCC. The model is available for fundamental investigations of the viral and molecular mechanisms responsible for hepatocarcinogenesis and should have substantial value for future development of innovative methods for chemoprevention and gene therapy of human HCC.

$\mathrm{T}$ he etiologic role of the hepatitis B virus (HBV) in hepatocarcinogenesis is well established from basic, epidemiological, and clinical research studies. The strongest evidence of the role of this virus is from results of newborn and infant vaccination that has resulted in remarkable reductions in the rate of chronic HBV infection in children and with a concomitant reduction in juvenile hepatocellular carcinoma (HCC). One can be reasonably certain the decreased rate of chronic HBV infection will result in a continued reduction in the incidence of HCC as the vaccinated population ages.

For those chronically infected with HBV, the prognosis remains unfavorable and improved methods of treatment and prevention of HCC are urgently needed. To make the breakthroughs that are required, preclinical animal research is essential. In almost all studies of the role of dietary or other environmental factors in hepatocarcinogenesis or of the development of strategies for chemoprevention, chemically induced models of HCC have been used. The single most important risk factor for $\mathrm{HCC}$ on a worldwide basis is chronic HBV infection and, of increasing concern, infection with HCV. Although aflatoxin may have a primary role in some cases of human $\mathrm{HCC}$ or interact with HBV in hepatocarcinogenesis, the essential primary role of hepatitis viruses is generally recognized. The objective of this report is to review the current knowledge of the pathogenesis of experimental woodchuck hepatitis virus (WHV) infection, to describe the etiologic role of WHV in hepatocarcinogenesis, and finally to consider current and potential uses of this animal model for the discovery and preclinical evaluation of new strategies for the treatment and prevention of HCC.

Abbreviations used in this paper: HBV, hepatitis B virus; HCC, hepatocellular carcinoma; FAH, foci of altered hepatocytes; GSHV, ground squirrel hepatitis virus; MRI, magnetic resonance imaging; RE, reticuloendothelial; TK, thymidine kinase; WHcAg, woodchuck hepatitis core antigen; WHsAg, woodchuck hepatitis surface antigen; WHV, woodchuck hepatitis virus.

(C) 2004 by the American Gastroenterological Association 0016-5085/04/\$30.00 doi:10.1053/j.gastro.2004.09.043 


\section{Naturally Acquired WHV Infection and HCC}

Hepatocellular adenomas were described in woodchucks (Marmota monax) from the Philadelphia Zoological Garden during the early part of the 20th century. ${ }^{1,2}$ Hepatocellular carcinomas subsequently were described in a woodchuck from the Washington Zoological Park and in another trapped within the city limits of Bethesda, MD. ${ }^{3}$ Cases of HCC also were reported in laboratory-maintained woodchucks trapped originally in New York, ${ }^{4}$ Maryland, ${ }^{5}$ and Pennsylvania. ${ }^{6,7}$

WHV was described by Summers et al. ${ }^{8}$ in a colony of woodchucks maintained at the Philadelphia Zoological Garden and that for some years had experienced high rates of chronic hepatitis and HCC. It was concluded that WHV belonged to the HBV family of viruses, and WHV now is classified as a member of the family Hepadnaviridae, genus Orthohepadnavirus, of which human $\mathrm{HBV}$ is the prototype.

The natural habitat of the woodchuck (ground hog) extends from northern Georgia, Alabama, and Mississippi in the southern United States; west to Oklahoma, Kansas, Nebraska, and North and South Dakota; north to Quebec and Labrador; and across Canada to British Columbia and the Yukon Territory and includes an area of southeastern Alaska. A comprehensive, seroepidemiologic study of WHV infection has not been performed, and the prevalence of infection throughout most of this range remains unknown. WHV infection is known to be hyperendemic in the mid-Atlantic states, and the woodchucks originally studied by Summers et al. ${ }^{8}$ were from Pennsylvania. In 1 seroepidemiological study, $23 \%$ of the woodchucks from Pennsylvania, New Jersey, and Maryland tested positive for WHV surface antigen (WHsAg), and 36\% were positive for antibody (anti-WHs) for an overall infection rate of $59 \%, 9$ and similarly high rates of WHV infection in the mid-Atlantic states have been observed by others. ${ }^{10}$ In contrast, the rate of WHV infection in central New York State was approximately $2 \%$, based on the prevalence of anti-WHs, ${ }^{10}$ and we estimate that the rate of persistent WHs antigenemia in woodchucks from Tompkins County, New York, is approximately $0.2 \%$. No serologic evidence of WHV infection has been found in Vermont, Massachusetts, or in Iowa, although the numbers tested from these areas so far have been small. ${ }^{11-13}$

The hepatic neoplasms associated with naturally acquired WHV infection characteristically have been welldifferentiated, trabecular HCCs. ${ }^{14}$ In most cases, chronic, active hepatitis was present with abundant mononuclear cell infiltration of portal tracts that sometimes extended beyond the limiting plate. There also was scattered pa- renchymal hepatocellular necrosis, bile duct proliferation, and in some cases evidence of early fibrosis, ${ }^{14-17}$ but hepatic cirrhosis was not characteristic. Progression of neoplasia from foci of altered hepatocytes $(\mathrm{FAH})$ to small neoplastic nodules and to frank HCC was recognized and some HCCs contained significant numbers of infiltrating hematopoietic cells. ${ }^{16,17}$ Metastasis of HCC outside the liver, which occurs in humans and other experimental animal models with some frequency, has not been reported in woodchucks by most investigators, although pulmonary metastases have been described. ${ }^{17}$

\section{Experimental WHV Infection}

The original observations on WHV were made with woodchucks that had been trapped in the native habitat and then maintained in the laboratory. Woodchucks with naturally acquired, chronic WHV infection were valuable sources of virus and hepatic tissue for molecular and histologic analyses. Susceptible, wild woodchucks that had been trapped also were used in experimental studies of WHV infection. Summers et al. ${ }^{18}$ reported results of the experimental infection of 4to 8-month-old woodchucks with serum from chronic WHV carriers. Although productive infection was shown, infection was self-limited, and none of the animals became chronic carriers. Other attempts to experimentally infect susceptible juvenile or adult woodchucks trapped in the native habitat also resulted in acute WHV infection but in almost all cases were self-limited and did not result in chronicity. ${ }^{10,19}$

From the beginning, the limitations of the use of wild woodchucks for experimental studies were recognized. It was impossible, for example, to know at what age and for how long trapped woodchucks had been infected with WHV or to be certain about nutritional or environmental factors that could influence the outcome of WHV infection. Importantly, hepatic lesions caused by Ackertia mannotae and Capillaria sp. that are common parasites of wild woodchucks ${ }^{20}$ complicated the interpretation of experimental results. To use the woodchuck as an experimental animal model, the National Institute of Allergy and Infectious Diseases and the National Cancer Institute jointly supported the establishment of a breeding colony of woodchucks at Cornell University in 1980. The colony has served as a source of laboratory born and reared woodchucks for studies of the pathogenesis WHV infection, for preclinical antiviral drug development, and for studies of viral hepatocarcinogenesis.

Woodchucks born in the colony are inoculated at birth with dilute serum from standardized infectious pools obtained from chronic, WHV-carrier woodchucks. The 


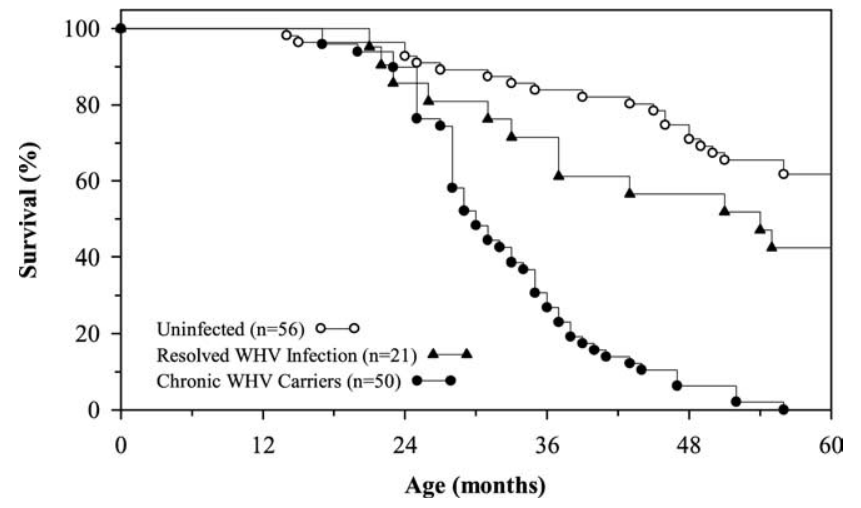

Figure 1. Kaplan-Meier survival analysis of 50 neonatally infected, chronic WHV carrier woodchucks and 21 woodchucks similarly infected at birth but in which WHV infection was resolved (clearance of viremia and development of anti-WHs antibody) compared with 56 uninfected controls. Survival of WHV carriers was significantly decreased compared with control woodchucks or woodchucks in which neonatal WHV infection was resolved. All 51 chronic WHV carriers' death was attributed to $\mathrm{HCC}$ or $\mathrm{HCC}$ was present at the time of death from other intercurrent diseases. HCC was diagnosed in 6 of the 21 woodchucks in which neonatal WHV infection had resolved. HCC was not found in any of the uninfected control woodchucks. Reprinted with permission. ${ }^{23}$

rate of chronic WHV infection following neonatal inoculation characteristically is $60 \%$ or higher. ${ }^{21,22}$ KaplanMeier survival analyses have been performed comparing chronic WHV carriers, woodchucks in which neonatal WHV infection was resolved (WH viremia cleared and anti-WHs antibody detected), and uninfected control woodchucks born and raised under similar laboratory conditions (Figure 1). ${ }^{23}$ All WHV carriers at 56 months of age had either died of HCC or died from intercurrent diseases but with HCC. In contrast, $42 \%$ of the woodchucks with resolved WHV infection and $62 \%$ of uninfected controls were alive after 56 months. HCC developed in $19 \%$ of woodchucks in which experimental WHV infection was resolved. HCC was not observed in uninfected, laboratory-reared woodchucks in this study and is rare in woodchucks that have not been exposed to WHV.

The gross appearance (Figure $2 \mathrm{~A}$ ) and the rate of HCC observed in woodchucks with experimentally induced chronic hepatitis were similar to those reported in woodchucks with naturally acquired chronic WHV infection. The histologic appearance of hepatitis (Figure 2B), of
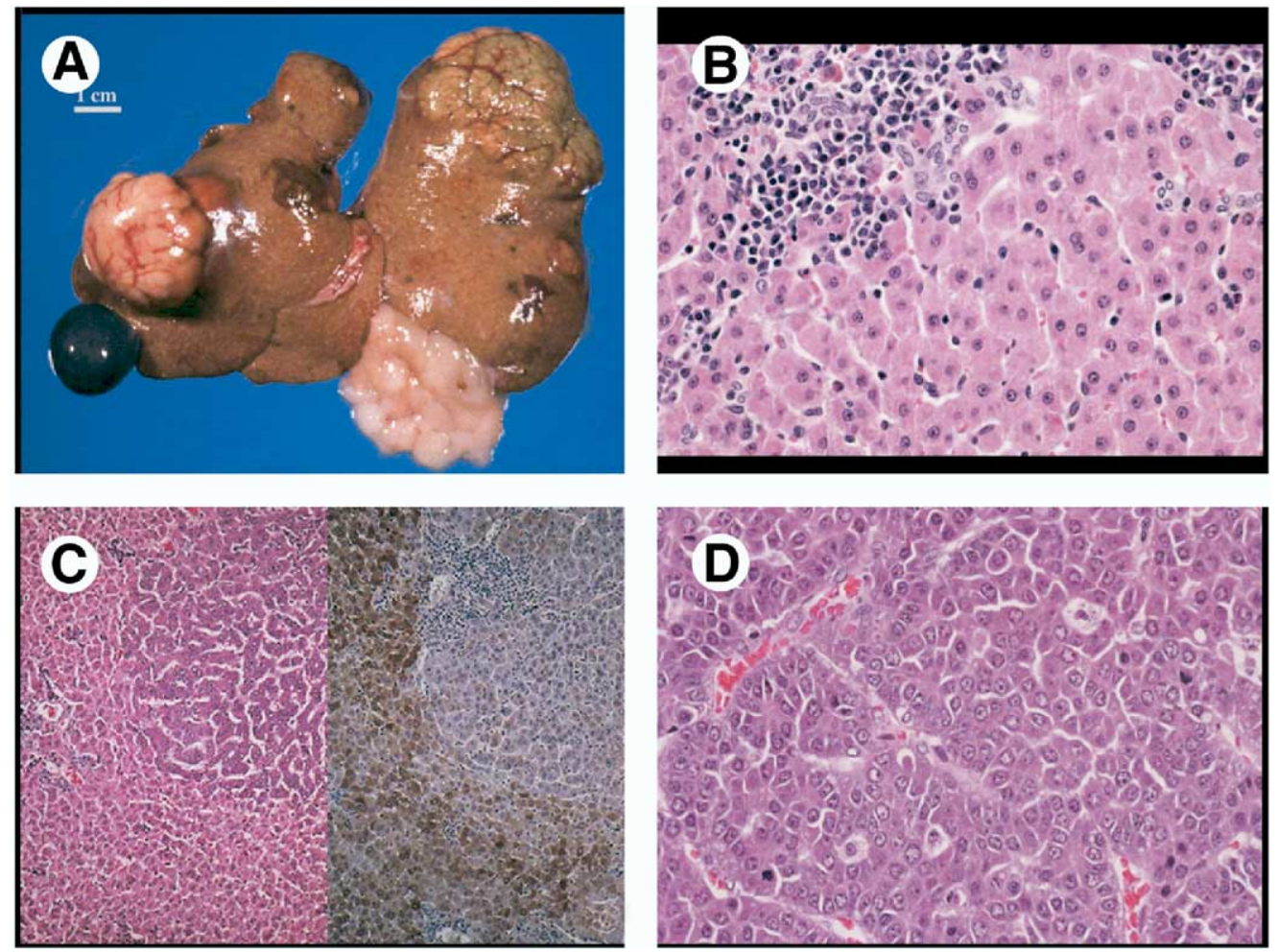

Figure 2. $(A)$ The liver of a chronic WHV carrier woodchuck showing multiple hepatocellular neoplasms (HCC) of varying size protruding from the diaphragmatic surface. $(B)$ Photomicrograph of the liver of a WHV carrier woodchuck showing chronic portal and parenchymal hepatitis with mononuclear cell expansion of a portal tract (upper left) and extension of the inflammatory infiltrate beyond the limiting plate. $(C) \mathrm{A}$ basophilic focus of altered hepatocytes (FAH) stained with hematoxylin and eosin (left) and a nearby section stained using a immunohistochemical procedure for WHcAg (right). The nonneoplastic hepatocytes are stained intensely in a mosaic pattern for WHcAg, whereas only a few of the cells of the FAH appear to express WHcAg. $(D)$ Photomicrograph of an undifferentiated HCC showing more malignant characteristics including broad trabeculae and mitotic figures. 
preneoplastic FAH (Figure 2C), and of HCC (Figure 2D) also were identical. These results provide direct experimental evidence for the oncogenicity of WHV and, by analogy, for other hepadnaviruses including HBV, the California ground squirrel hepatitis virus (GSHV), the arctic ground squirrel hepatitis virus, and for the less well-characterized hepadnavirus of Richardson's ground squirrels in which naturally acquired infection has been associated with HCC. ${ }^{23}$

\section{Histogenesis of Experimental HCC in Woodchucks}

Hepatocarcinogenesis generally is recognized as a multistage process. In chemically induced rodent models, development of adenoma and/or HCC is preceded by the appearance of microscopic $\mathrm{FAH}$ that are similar to those observed in chronic WHV infection. ${ }^{24-26}$ Dysplastic changes in hepatocytes have been recognized in humans with chronic HBV infection and in some cases have been considered to be precancerous in nature. More recently, FAH have been described in the livers of patients undergoing liver transplantation for chronic, end-stage viral hepatitis with or without HCC and are essentially identical to those caused by chemical hepatocarcinogens in rats and mice and that are characteristic of chronic WHV infection. ${ }^{27}$

We have investigated the development of $\mathrm{FAH}$ in woodchucks with experimentally induced chronic WHV infection. The earliest detection of FAH in chronic WHV carriers was at 6 months of age. By 9-10 months, more than $30 \%$ of WHV carriers had such lesions and, thereafter, almost all the livers of chronic WHV carriers examined contained FAH (Figure 3). Small HCCs in experimentally induced chronic WHV infection have been observed as early as 9 months of age. The median time to tumor detection by ultrasonography in the model was 24 months, and the median time to death associated with HCC was $29-30$ months of age (Figure 1). ${ }^{23}$

\section{Molecular Genetic Alterations in HCC Associated With WHV Infection}

Integrated hepadnaviral nucleic acid sequences have been shown in the cellular DNA of most hepatic tumors of woodchucks chronically infected with WHV, and, as in HBV infection, a direct molecular role of hepadnaviruses in hepatocarcinogenesis has been hypothesized. Integration of hepadnaviral nucleic acid sequences is believed to be a critical mutagenic event that alters the expression of cellular regulatory genes (protooncogenes,

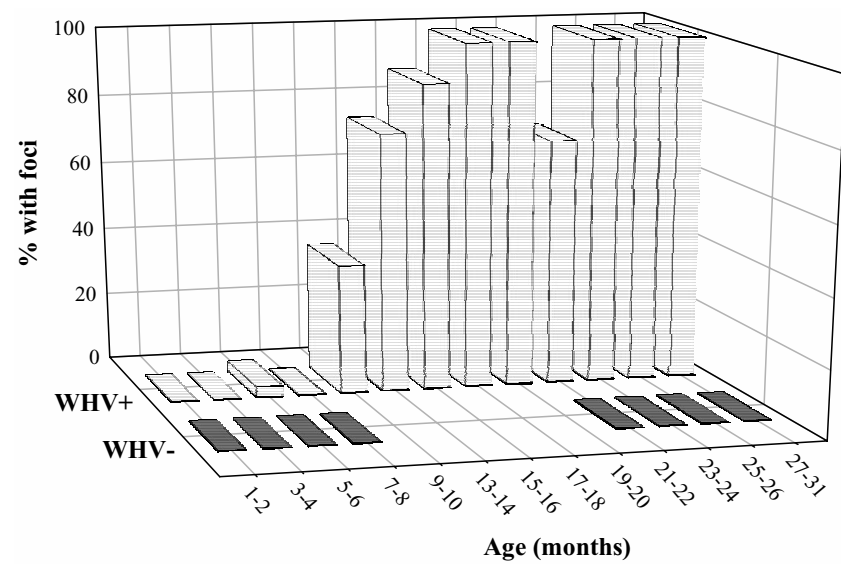

Figure 3. The percentage of liver sections from woodchucks of different ages that contained foci of altered hepatocytes (FAHs). WHV-, woodchucks were not exposed to WHV and tested negative for serologic markers of WHV infection; WHV + , woodchucks were neonatally infected with WHV. From 1 to 8 months of age, the woodchucks studied included woodchucks that were serologically positive for WHV and would have become chronic carriers and other woodchucks either serologically positive or negative for WHV and were in the process of resolving the infection. All woodchucks over 9 months of age were viremic and considered to be chronic carriers. At 9-10 months of age, more than $30 \%$ of liver specimens contained FAH. Thereafter, almost all sections contained FAH.

tumor suppressor genes) that ultimately results in the neoplastic transformation of hepatocytes.

Fourel et al. ${ }^{28}$ have shown that $N-m y c$ mRNA was overexpressed in $60 \%$ of woodchuck HCCs examined, and this transcript was not detectable in normal woodchuck liver. Woodchucks were found to have $2 \mathrm{~N}$-myc loci. One N-myc locus was homologous to other mammalian $N-m y c$ genes. The other was an intronless gene with the characteristic structure of a retrotransposon and was called $N-m y c 2 .{ }^{28}$ The expression of $N-m y c 2$, which has been mapped to the $\mathrm{X}$ chromosome, is highly restricted, and the brain is the only normal woodchuck tissue in which $N$-myc2 RNA has been detected. ${ }^{29}$ The functional significance of $\mathrm{N}-m y c 2$ remains unknown, but current evidence indicates that a distinctive feature of hepatocarcinogenesis in woodchucks with chronic WHV infection is viral integration into or near the myc family of proto-oncogenes. ${ }^{23}$

In both naturally acquired and experimental WHV infection, viral integrations seem to be preferentially associated with the N-myc2 locus and are clustered either within a $3-\mathrm{kb}$ region upstream of $N-m y c 2$ or in the $3^{\prime}$ noncoding region of the gene. ${ }^{30,31}$ Insertion of WHV enhancer sequences either upstream or downstream of the $N-m y c 2$ coding domain results in increased production of either normal $N-m y c 2$ RNA or of a hybrid $N-m y c 2 / W H V$ transcript that is initiated at the normal $N-m y c 2$ start site. Transcriptional activation of $m y c$ family proto-onco- 
genes by enhancer insertion seems to be a common mechanism, ${ }^{32}$ and a recently identified liver-specific regulatory element in the WHV genome appears to control cis activation $\mathrm{N}-m y c 2 .{ }^{33}$ Distant, downstream integration of WHV DNA on the X chromosome at 2 separate sites also been associated with $N$-myc2 activation. ${ }^{34}$

Buendia and colleagues have reported transgenic mice carrying the N-myc2 gene under the control of WHV regulatory sequences. These mice were highly predisposed to liver cancer, ${ }^{35}$ and $70 \%$ develop hepatocellular adenomas or HCC. A transgenic founder mouse carrying the unmethylated WHV/N-myc2 transgene sequence died at 2 months of age with a large hepatic tumor, showing the high oncogenic capacity of the woodchuck $\mathrm{N}-m y c$ retroposon. Mutations or deletions of the betacatenin gene were present in $25 \%$ of the hepatic tumors of the N-myc2 transgenic mice and were similar to those reported in HCCs of humans. ${ }^{36}$ When $N-m y c 2$ transgenic mice were crossed with $p 53$ null mice, the absence of 1 p53 allele markedly accelerated the onset of liver cancer, providing experimental evidence for synergy between activation of the N-myc2 gene and decreased expression of p53 in hepatocarcinogenesis. ${ }^{36}$

Like the woodchuck, the California ground squirrel possesses an N-myc2 locus that is transcriptionally active in the brain. ${ }^{37}$ Increased $N-m y c 2$ expression is unusual in the HCCs of California ground squirrels infected with GSHV. Amplification of $c-m y c$ expression, however, is more frequent in ground squirrels than in woodchucks. ${ }^{38}$ Marion et al. ${ }^{39}$ have shown that HCC characteristically develops less frequently in GSHV-infected ground squirrels than in WHV carrier woodchucks, and in ground squirrels, HCC characteristically develops at an older age.

Seeger et al. ${ }^{40}$ showed that woodchucks were susceptible to GSHV infection. They successfully infected neonatal woodchucks with both WHV and GSHV and compared the oncogenic potential of the 2 viruses in the same host species. HCC developed at a significantly earlier age in WHV carrier woodchucks than in woodchucks chronically infected with GSHV. Hepatocellular carcinomas from these woodchucks have been analyzed by Hansen et al. ${ }^{41}$ They confirmed the propensity for WHV genomic DNA to integrate in or near the N-myc2 locus in HCCs from WHV carriers. Seven of 17 WHVinduced tumors ( $41 \%$ ) had demonstrable rearrangements of the $N-m y c 2$ allele, whereas only 1 of 16 woodchuck tumors induced by GSHV (6\%) had such an N-myc2 rearrangement. Comparable results were obtained when $N-m y c 2$ gene expression was determined. Based on these observations, it was concluded that the differences in hepadnavirus insertion and $N-m y c 2$ activation between

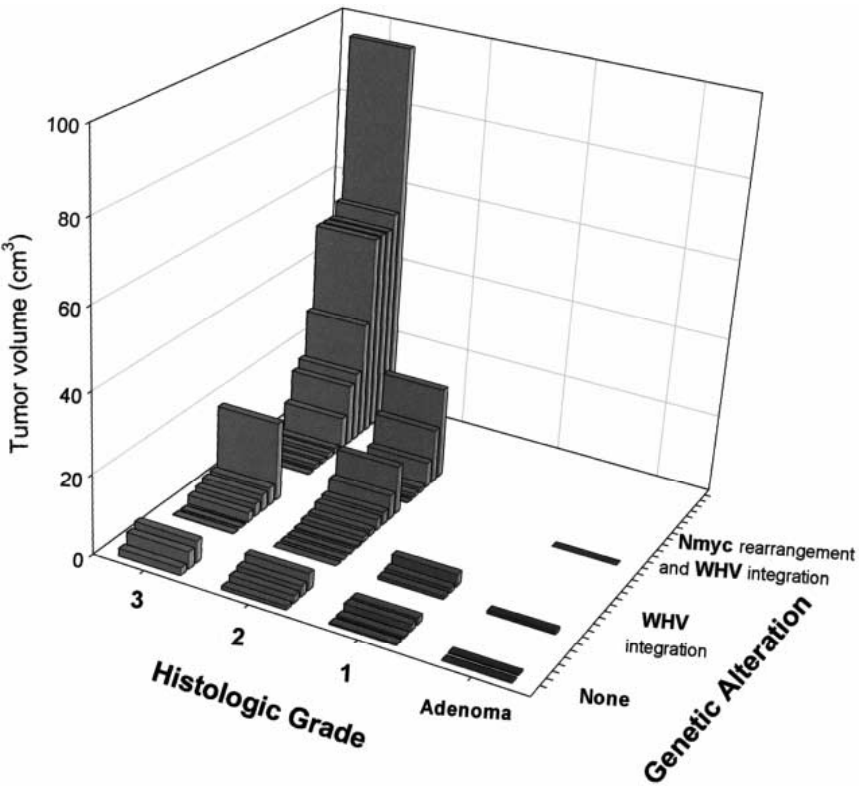

Figure 4. Relationship between histologic grade of tumor (x axis), the tumor volume (y axis), and the status of WHV DNA integrations and $\mathrm{N}$-myc rearrangement ( $\mathrm{z}$ axis) of 55 hepatic tumors. Tumors exhibiting both WHV integration and N-myc rearrangement were predominately large, grade $3 \mathrm{HCC}$. The largest tumors and those that were less differentiated (grade 2 and 3) characteristically exhibited both WHV integrations and rearrangement of the $\mathrm{N}$-myc gene. Reprinted with permission. ${ }^{42}$

woodchucks and California ground squirrels were related primarily to genetic differences in the respective viruses rather than to differences in the animal host. ${ }^{37,41}$

\section{Relationship of Size and Histologic Grade of Hepatic Tumors to WHV Integration and $\mathbf{N}$-myc Rearrangement}

Jacob et al. ${ }^{42}$ have investigated the relationship between the size and histologic grade of hepatic neoplasms of woodchucks and the presence of WHV DNA integrations and $N-m y c 2$ rearrangements. The 13 chronic WHV-carrier woodchucks of their study ranged in age from 24 to 39 months (median age, 30 months) and had been born, reared, and maintained in a laboratory environment. The clinical diagnosis of HCC was based initially on increasing serum activity of gammaglutamyltransferase and on hepatic ultrasound examinations. Fifty-five hepatocellular neoplasms and matched nontumorous hepatic tissue were obtained postmortem and the frequency of WHV DNA integrations and of N-myc rearrangements compared in tumors of different size and histologic grade (Figure 4).

Four small tumor nodules were classified histologically as adenomas. Integrated sequences of WHV DNA were 
detected in 2 of the 4 , and in 1 of the 2 , there was evidence of $\mathrm{N}$-myc rearrangement. Fifty-one of the neoplasms were classified as HCC. Seven were grade 1 HCCs, and WHV DNA integrations were shown in $43 \%$, but none had N-myc rearrangements. In 20 grade 2 HCCs, $80 \%$ had WHV DNA integrations, and, in $38 \%, \mathrm{~N}$-myc rearrangements also were detected. In 24 grade 3 HCCs, integrations of WHV DNA were present in $79 \%$, and, in $74 \%$, rearrangements were present in $\mathrm{N}$-myc. In 2 other grade $3 \mathrm{HCCs}$, rearrangements of $\mathrm{N}$-myc were detected in the absence of WHV DNA integrations. The 12 largest tumors in the series all were grade 2 or 3 HCCs, and, in $83 \%$, both WHV DNA integrations and $\mathrm{N}$-myc rearrangements were shown. The molecular changes observed in this study suggest a progression in genetic alterations that provide a proliferative stimulus and/or growth advantage during hepatocarcinogenesis associated with chronic WHV infection.

\section{Preclinical Evaluation of Efficacy and Safety of Antiviral Drugs Using the Woodchuck Model of Hepatitis B Virus Infection}

Woodchucks with experimentally induced chronic WHV infection have been used successfully in the preclinical assessment of antiviral drugs during development for treatment of chronic HBV infection. Both nucleoside analogs ${ }^{43,44}$ and immune-response modifiers have been evaluated. ${ }^{45,46}$ Before use in woodchucks, drugs have been tested for antiviral activity against HBV in the 2.2 .15 cell system. ${ }^{47}$ Acyclovir and zidovudine were shown to have no in vitro activity against $\mathrm{HBV}$ in 2.2.15 cells and had no antiviral activity against WHV in the woodchuck model. ${ }^{43}$ Arabinofuranosyl-adenosine monophosphate, which had moderate antiviral activity in vitro, had significant antiviral activity in woodchucks in vivo at a parenteral dose of $15 \mathrm{mg} / \mathrm{kg}$ per day. Most nucleoside analogs with moderate antiviral activity against HBV in 2.2.15 cells had comparable antiviral activity in woodchucks. The 2 exceptions were fialuridine and clevudine, both of which had relatively low in vitro activity but had potent antiviral activity when administered orally to woodchucks. In woodchucks, fialuridine had significant, delayed hepatotoxicity associated with microvesicular steatosis and mitochondrial injury similar to the hepatotoxic effects of fialuridine observed in humans. ${ }^{48}$

Lamivudine, which has among the highest selective indices of in vitro activity in the 2.2 .15 cell system ${ }^{43}$ and has favorable pharmacokinetics in woodchucks, ${ }^{49}$ has variable antiviral activity in the woodchuck model based on reduction in serum viral $\operatorname{load}^{43,44,50,51}$ and does not exhibit a significant effect on hepatic covalently closed circular WHV DNA in cultured woodchuck hepatocytes, which may be attributed to the absence of cell division in hepatocytes in culture. ${ }^{52}$ Extended lamivudine treatment of woodchucks with chronic WHV infections delayed the development of HCC and significantly extended survival in one study. ${ }^{53}$ In a second study, however, no effect of lamivudine on hepatocarcinogenesis was observed. ${ }^{50}$ In the second study, treatment was initiated at an older age, the duration of treatment was shorter, and the observed effect of treatment on viral load was less than that observed in the first study. High rates of mutation in the WHV polymerase gene were associated with development of high rates of lamivudine resistance in both studies, ${ }^{54,55}$ similar to observations in HBV patients treated long-term with lamivudine. ${ }^{56-58}$

Lamivudine drug resistance has been induced experimentally in chronic WHV carriers as a model for preclinical evaluation of nucleoside/nucleotide drugs being developed for treatment of lamivudine-resistant HBV infection. ${ }^{59}$ The woodchuck model has been used to evaluate combination therapy with lamivudine and famciclovir $^{60}$ and with lamivudine and alpha-interferon ${ }^{51}$ to assess possible additive or synergistic effects. Specific hepatic targeting of antiviral drugs to increase efficacy and possibly to diminish nonhepatic toxicity has been shown using the woodchuck model. ${ }^{61,62}$ Importantly, second- and third-generation antiviral nucleosides including emtricitabine, ${ }^{63}$ clevudine ${ }^{64}$ entecavir, ${ }^{65,66}$ and telbivudine ${ }^{67,68}$ have been tested for safety and efficacy in the woodchuck model before the initiation of the advanced clinical trials that are now in progress.

\section{Chemoprevention of Hepatocellular Carcinoma in Woodchucks Using Long-Term Nucleoside Analog Therapy}

In the study reported by Colonno et al., ${ }^{65}$ the guanosine nucleoside, entecavir, which has potent antiviral activity against WHV and $\mathrm{HBV}$, was used to determine the influence of long-term suppression of viral replication on hepatocarcinogenesis in woodchucks. Beginning at 8 months of age, WHV carriers were given entecavir orally at a dose of $0.5 \mathrm{mg} / \mathrm{kg}$ per day for 8 weeks and then weekly at a dose of $0.5 \mathrm{mg} / \mathrm{kg}$ per week. In 6 woodchucks, treatment was stopped after a total of 14 months, and, in 5 , treatment was continued for a total of 36 months. Hepatic expression of viral antigens and covalently closed circular WHV DNA were significantly reduced by long-term entecavir treatment of wood- 
chucks. Three of the 6 woodchucks treated for 14 months had sustained antiviral responses and developed no evidence of HCC during the next 2 years. In woodchucks treated for 36 months, there was no evidence of HCC in 4 of the 5 (80\% HCC-free survival). Compared with historical controls in which 4-year HCC survival was $4 \%$, entecavir treatment significantly delayed development of HCC and prolonged survival $(P<0.01)$.

In a second study of long-term antiviral therapy reported by Menne et al. ${ }^{69} 1$ - and 2-year-old woodchucks were treated for 32 weeks with the highly potent nucleoside clevudine (10 mg/kg per day), whereas woodchuck controls received placebo. Half of clevudine-treated woodchucks and half of the placebo recipients then received 4 doses of alum-adsorbed WHsAg vaccine during the next 16 weeks. Vaccination alone elicited low-level antibody responses to WHsAg in most carriers but did not affect serum WHV DNA, serum WHsAg, or liver enzyme responses. Carriers treated first with clevudine to reduce serum WHV DNA and WHsAg and then vaccinated developed a more robust anti-WHs response and normalized liver enzymes. After vaccination, WHsAgspecific cell-mediated immunity was shown in both vaccinated groups but was significantly enhanced in carriers treated initially with clevudine and was broadened to include responses to WHV core antigen (WHcAg) and to selected peptide epitopes of WHcAg and WHsAg. It was concluded that vaccination with WHsAg after clevudine-disrupted virus-specific humoral and cell-mediated immune tolerance enhanced the immune response profiles beyond those seen with either clevudine or with vaccine monotherapy. Therapy with the clevudine-vaccine combination resulted in immune response profiles that resembled those observed during resolution of experimental WHV infection.

In 10 of the woodchucks reported by Menne et al., ${ }^{69}$ clevudine treatment (with or without vaccine) was initiated at 1 year of age. Marked and sustained reductions in serum WHV DNA and WHs antigenemia were observed during treatment and for a period of 18 months after drug withdrawal. Liver biopsies were obtained at the time treatment was initiated, at the end of treatment (20 months of age), and 6 and 12 months after drug withdrawal (24 and 32 months of age). At every time point after clevudine treatment was begun, hepatic WHV nucleic acids and WHcAg expression were reduced compared with placebotreated controls. The percentage of biopsies with FAH was significantly lower in the clevudine-treated group than in controls (Figure 5). The development of HCC also was delayed, and the survival at 3 years of age in the 10 clevudine-treated woodchucks was $50 \%$ com-

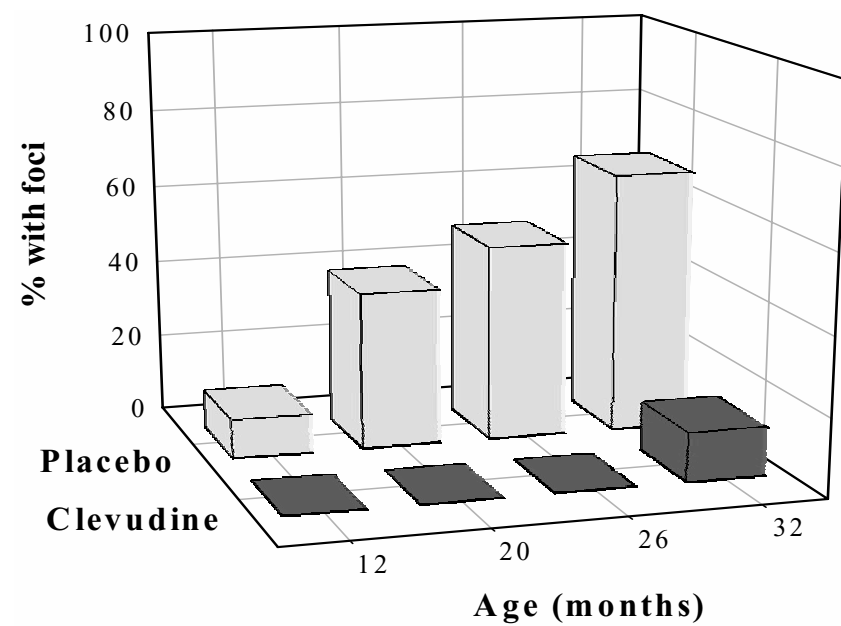

Figure 5. The percentage of liver biopsies from 10 chronic WHV carrier woodchucks treated with clevudine orally (10 mg/kg per day) beginning at 12 months that contained foci of altered hepatocytes (FAHs) compared with 10 placebo-treated controls. In the woodchucks treated with clevudine (with or without vaccine, reported by Menne et al. ${ }^{69}$ ), there were marked and sustained reductions in serum WHV DNA and WHs antigenemia during treatment and for a period of 18 months after drug withdrawal. Liver biopsies were obtained when treatment was initiated (12 months of age), at the end of treatment (20 months of age), and 6 and 12 months after drug withdrawal (24 and 32 months of age). At every time point after clevudine treatment was initiated, the percentage of biopsies with FAH was significantly decreased in clevudine-treated woodchucks and the development of $\mathrm{HCC}$ was delayed and 3- and 4-year survival was increased. (See text for details.)

pared with $25 \%$ in controls $(P=0.065)$. After 4 years, the survival in the clevudine group was $25 \%$ compared with $6 \%$ in controls $(P=0.035)$.

In a third, long-term study of chemoprevention, 20 8-month-old WHV carriers were treated for life with lamivudine ( $5 \mathrm{mg}$ then $15 \mathrm{mg} / \mathrm{kg}$ per day), and 20 carrier controls were treated with placebo. ${ }^{53}$ Serum WHV DNA decreased by $4-5$ logs in lamivudine-treated woodchucks, and the antiviral effect was sustained for more than 1 year. Thereafter, recrudescence of viral replication was detected that was associated with mutations of the WHV polymerase B domain gene. ${ }^{55}$ There was a significant delay in the development of HCC in lamivudinetreated woodchucks and a corresponding increase in survival. The median time to death in placebo-treated controls was 32 months and in lamivudine-treated woodchucks was 44 months $(P=0.01)$. A similar beneficial effect on HCC development was described recently in a controlled clinical trial in chronic HBV carriers treated for a median period of 32 months with lamivudine. During the study, HCC developed in 16 of $215(7 \%)$ placebo-treated control patients and in 17 of $436(4 \%)$ patients treated with lamivudine $(P=0.047) .{ }^{70}$ 


\section{Preclinical Assessment of Diagnostic Imaging Technology Using the Woodchuck Model of Hepatitis B Virus Infection}

Ultrasonography has been useful in the detection of HCC during the course of chronic WHV infection in laboratory-maintained woodchucks. ${ }^{71-73}$ Woodchucks with HCC have been useful for preclinical development of contrast agents for enhancement of both color Doppler and gray scale ultrasonography including those that use microbubble technology, ${ }^{74-77}$ other vascular imaging agents, ${ }^{78,79}$ and agents taken up by the reticuloendothelial (RE) system. ${ }^{80}$ By increasing the sensitivity of tumor growth measurements or by improving the evaluation of hepatic tumor regression, these methods may be useful in future experimental studies of chemoprevention or of HCC therapy in woodchucks.

Magnetic resonance imaging (MRI) has also been used successfully for the quantitative evaluation of HCC in woodchucks. Iron oxide has been administered parenterally to woodchucks with HCC as an MRI contrast agent. ${ }^{81}$ The iron was taken up primarily by the RE system, and the MRI contrast was the result of relatively more iron being taken up by RE cells of the nonneoplastic hepatic parenchyma than by the hepatic tumors, which are relatively free of RE activity. An arabinogalactan conjugate of ultrasmall particles of superparamagnetic iron oxide was used to target the asialoglycoprotein receptor of the hepatocyte. ${ }^{82}$ When given intravenously, MRI contrast was enhanced because the conjugated iron was taken up by the nonneoplastic hepatocytes that contain the asialoglycoprotein receptor but not by hepatic tumor cells which lack the receptor. MR receptor imaging may have a role in experimental studies to differentiate between primary liver tumors and mass lesions of the liver composed of functionally normal hepatocytes (e.g., regenerating nodules). Hepatic imaging using single photon emission computed tomography and/or positron immersion tomography may be even more valuable in understanding the kinetics of molecular and cellular changes if liver cells from the beginning of the process of viral hepatocarcinogenesis can be investigated.

\section{Woodchuck Model in the Molecular Therapy of HCC}

There has been significant interest in gene therapy for HCC and the woodchuck has been a useful animal model. Bilbao et al. ${ }^{83}$ have investigated whether an adenoviral cytomegalovirus thymidine kinase (TK) construct could induce an antitumoral effect in woodchucks with HCC. In a preliminary study, the vector was injected either directly into the hepatic tumor or was administered by injection directly into the hepatic artery. A significant number of tumor cells were transduced by both methods even in large tumors. Subsequent ganciclovir administration caused a significant antitumoral effect in 2 woodchucks. A third woodchuck died of acute liver failure, attributed to TK expression in nonneoplastic hepatic cells. The later finding indicated the need to have TK expression under the control of a liver tumor-specific promoter.

In another gene therapy study reported by Putzer et al., ${ }^{84}$ HCCs of woodchucks were transformed by direct injection of an adenovirus vector containing the murine IL-12 and B7.1 genes. Regression of tumors injected with the therapeutic virus (AdIL-12/B7.1) was compared postmortem to tumors treated with control virus. In all tumors treated with AdIL-12/B7.1, significant tumor regression was observed and this was associated with increased numbers of $\mathrm{CD} 4(+)$ and $\mathrm{CD} 8(+)$ lymphocytes and interferon gamma. In 1 woodchuck monitored by MRI, intratumoral vector administration was associated with almost complete tumor regression within 7 weeks. It was concluded that adenoviral-based immunotherapy was effective in the woodchuck model, and development of this approach for use in human patients with HCC should be continued.

\section{Summary and Conclusions}

Woodchucks have been a valuable experimental animal for investigation of the pathogenesis of $\mathrm{HBV}$ infection and of the role of $\mathrm{HBV}$ in hepatocarcinogenesis. Woodchucks also have been important in the preclinical evaluation of the safety and efficacy of antiviral drugs now in use for treatment of HBV infection and continue to serve as an important, predictive model for development of second- and third-generation antiviral nucleosides/nucleotides and immune response modifiers alone or in combination. Almost all chronic WHV-carrier woodchucks develop HCC with a median HCC-free survival of 24 months and a median life expectancy of 30-32 months. The model has been used effectively for the development of new imaging agents to enhance the early detection of hepatic neoplasms by ultrasound and MRI. The chemoprevention of HCC using long-term antiviral nucleoside therapy has been shown in the woodchuck, and "proof of principal" has been established for innovative gene therapy of HCC. The laboratory woodchuck now is available for fundamental investigations of the viral pathogenesis of hepatic neoplasia, and, in the future, should become increasingly important for devel- 
opment of improved methods of chemoprevention and molecular therapy for human HCC.

\section{References}

1. Fox H. Observations upon neoplasms in wild animals in the Philadelphia Zoological Garden. J Pathol Bacteriol 1912;17:217231.

2. Ratcliffe HL. Incidence and nature of tumors in captive mammals and birds. Am J Cancer 1933;17:116-135.

3. Habermann RT, Williams FP, Eyestone WH. Spontaneous hepatomas in two woodchucks and a carcinoma of the testis in a badger. J Am Vet Med Assoc 1954;125:295-298.

4. Bond E. Hepatoma and arteriosclerosis in a woodchuck. J Wildl Dis 1970;6:418-421.

5. Long GG, Terrell TG, Stookey JL. Hepatomas in a group of captured woodchucks. J Am Vet Med Assoc 1975;167:589.

6. Snyder RL. Hepatomas of captive woodchucks. Am J Pathol 1968;52:32A-33A.

7. Snyder RL, Ratcliffe HL. Marmota monax: a model for studies of cardiovascular, cerebrovascular and neoplastic disease. Acta Zool Pathol Antverp 1969;48:265-273.

8. Summers J, Smolec JM, Snyder R. A virus similar to human hepatitis B virus associated with hepatitis and hepatoma in woodchucks. Proc Natl Acad Sci U S A 1978;75:4533-4537.

9. Tyler GV, Summers J, Snyder R. Woodchuck hepatitis virus in natural woodchuck population. J Wild Dis 1981;17:297-301.

10. Wong DC, Shih JW, Purcell RH, Gerin JL, London WT. Natural and experimental infection of woodchucks with woodchuck hepatitis virus as measured by new specific assays for woodchuck surface antigen and antibody. J Clin Microbiol 1982;15:484-490.

11. Lutwick LI, Hebert MB, Sywassink JM. Cross-reactions between the hepatitis B and woodchuck hepatitis viruses. In: Szmuness W, Alter HI, Maynard JE, eds. Viral hepatitis. Philadelphia: Franklin Institute Press, 1982:711-712.

12. Summers J. Three recently described animal virus models for human hepatitis B. Hepatology 1981;1:179-183.

13. Young RA, Sims EAH. The woodchuck, Marmota monax, as a laboratory animal. Lab Anim Sci 1979;29:770-780.

14. Snyder RL, Summers J. Woodchuck hepatitis virus and hepatocellular carcinoma. In: Essex M, Todaro G, zur Hausen H, eds. Viruses in naturally occurring cancers, book A. Cold Spring Harbor Conferences on Cell Proliferation, Cold Spring Harbor Laboratory, Cold Spring Harbor, NY, 1980:447-457.

15. Snyder RL, Tyler G, Summers J. Chronic hepatitis and hepatocellular carcinoma associated with woodchuck hepatitis virus. Am J Pathol 1982;107:422-425.

16. Popper H, Shih JWK, Gerin JL, Wong DC, Hoyer BH, London WT, Sly DL, Purcell RH. Woodchuck hepatitis and hepatocellular carcinoma: correlation of histologic with virologic observations. Hepatology 1981;1:91-98.

17. Roth L, King JM, Hornbuckle WE, Harvey HJ, Tennant BC. Chronic hepatitis and hepatocellular carcinoma associated with persistent woodchuck hepatitis virus infection. Vet Pathol 1985;22: 338-343.

18. Summers J, Smolec JM, Werner BG, Kelly TJ, Tyler GV, Snyder RL. Hepatitis $B$ virus and woodchuck hepatitis virus are members of a novel class of DNA viruses. In: Essex M, Todaro G, zur Hausen $H$, eds. Viruses in naturally occurring cancers, book A. Cold Spring Harbor Conferences on Cell Proliferation, Cold Spring Harbor Laboratory, 1980:459-470.

19. Millman I, Southam L, Halbherr T, Simmons H, Kang CM. Woodchuck hepatitis virus: experimental infection and natural occurrence. Hepatology 1984;4:817-823.

20. Cohn DL, Erb HN, Georgi JR, Tennant BC. Parasites of the laboratory woodchuck (Marmota monax). Lab Anim Sci 1986;36: 298-302.
21. Popper H, Roth L, Purcell RH, Tennant BC, Gerin JL. Hepatocarcinogenicity of the woodchuck hepatitis virus. Proc Natl Acad Sci U S A 1987;84:866-870.

22. Cote PJ, Korba BE, Miller RH, Jacob JR, Baldwin BH, Hornbuckle WE, Purcell RH, Tennant BC, Gerin JL. Effects of age and viral determinants on chronicity as an outcome of experimental woodchuck hepatitis virus infection. Hepatology 2000;31:190-200.

23. Tennant BC. Animal models of hepadnavirus-associated hepatocellular carcinoma. Clin Liver Dis 2001;5:43-68.

24. Abe K, Kurata T, Shikata T, Tennant BC. Enzyme-altered liver cell foci in woodchucks infected with woodchuck hepatitis virus. Jpn J Cancer Res 1988;79:466-472.

25. Toshkov I, Hacker HI, Roggendorf M, Bannasch P. Phenotypic patterns of preneoplastic and neoplastic hepatic lesions in woodchucks infected with woodchuck hepatitis virus. J Cancer Res Clin Oncol 1990;116:581-590.

26. Radaeva S, Li Y, Hacker HJ, Burger V, Kopp-Schneider A, Banasch P. Hepadnaviral hepatocarcinogenesis: in situ visualization of viral antigens, cytoplasmic compartmentation, enzymic patterns, and cellular proliferation in preneoplastic hepatocellular lineages in woodchucks. J Hepatol 2000;33:580-600.

27. Su Q, Benner A, Hofmann WJ, Otto G, Pichlmayr R, Bannasch P. Human hepatic preneoplasia: phenotypes and proliferation kinetics of foci and nodules of altered hepatocytes and their relationship to liver cell dysplasia. Virch Arch 1997;431:391-406.

28. Fourel G, Trepo C, Bougueleret L, Henglein B, Ponzetto A, Tiollais $\mathrm{P}$, Buendia MA. Frequent activation of $\mathrm{N}$-myc genes by hepadnavirus insertion in woodchuck liver tumors. Nature 1990;347: 294-298.

29. Fourel G, Transy C, Tennant BC, Buendia MA. Expression of the woodchuck $\mathrm{N}$-myc2 retroposon in brain and in liver tumors is driven by a cryptic N-myc promoter. Mol Cell Biol 1992;12:53365344.

30. Flajolet M, Gegonne A, Ghysdael J, Tiollais P, Buendia MA, Foure G. Cellular and viral trans-acting factors modulate N-myc2 promoter activity in woodchuck liver tumors. Oncogene 1997;15: 1103-1110.

31. Wei Y, Fourel G, Ponzetto A, Silvestro M, Tiollais P, Buendia MA. Hepadnavirus integration: mechanisms of activation of the $\mathrm{N}$ myc2 retrotransposon in woodchuck liver tumors. J Virol 1992; 66:5265-5276.

32. Wei Y, Tennant B, Ganem D. In vivo effects of mutations in woodchuck hepatitis virus enhancer II. J Virol 1998;72:66086611.

33. Fourel G, Ringeisen F, Flajolet M, Tronche F, Pontoglio M, Tiollais $P$, Buendia MA. The HNF1/HNF4-dependent We2 element of woodchuck hepatitis virus controls viral replication and can activate the N-myc2 promoter. J Virol 1996;70:8571-8583.

34. Fourel G, Couturier J, Wei Y, Apiou F, Tiollais P, Buendia MA Evidence for long-range oncogene activation by hepadnavirus insertion. EMBO J 1994;13:2526-2534.

35. Renard C-A, Fourel G, Bralet M-P, Degott C, De La Coste A, Perret C, Tiollais $\mathrm{P}$, Buendia MA. Hepatocellular carcinoma in WHV/N-myc 2 transgenic mice: oncogenic mutations of beta-catenin and synergistic effect of p53 null alleles. Oncogene 2000;19:2678-2686.

36. de La Coste A, Romagnolo B, Billuart P, Renard CA, Buendia MA, Soubrane O, Fabre M, Chelly J, Beldjord C, Kahn A, Perret C. Somatic mutations of the beta-catenin gene are frequent in mouse and human hepatocellular carcinomas. Proc Natl Acad Sci U S A 1998;95:8847-8831.

37. Quignon F, Renard CA, Tiollais P, Buendia MA, Transy C. A functional $\mathrm{N}$-myc2 retroposon in ground squirrels: implications for hepadnavirus-associated carcinogenesis. Oncogene 1996;12:2011-2017.

38. Transy C, Fourel G, Robinson WS, Tiollais P, Marion PL, Buendia MA. Frequent amplification of c-myc in ground squirrel liver tumors associated with past or ongoing infection with a hepadnavirus. Proc Natl Acad Sci U S A 1992;89:3874-3878. 
39. Marion PL, Van Davelaar MJ, Knight SS, Salazar FH, Garcia G, Popper H, Robinson WS. Hepatocellular carcinoma in ground squirrels persistently infected with ground squirrel hepatitis virus. Proc Natl Acad Sci U S A 1986;83:4543-4546.

40. Seeger C, Baldwin B, Hornbuckle WE, Yeager AE, Tennant BC, Cote P, Ferrell L, Ganem D, Varmus HE. Woodchuck hepatitis virus is a more efficient oncogenic agent than ground squirrel hepatitis virus in a common host. J Virol 1991;65:1673-1979.

41. Hansen L, Tennant BC, Seeger C, Ganem D. Differential activation of myc gene family members in hepatic carcinogenesis by closely related hepatitis B viruses. Mol Cell Biol 1993;13:659667.

42. Jacob JR, Sterczer A, Toshkov IA, Yeager AE, Korba BE, Cote PJ, Buendia MA, Gerin JL, Tennant BC. Integration of woodchuck hepatitis and $\mathrm{N}$-myc rearrangement determine size and histologic grade of hepatic tumors. Hepatology 2004;39:1008-1016.

43. Tennant BC, Baldwin BH, Hornbuckle WE, Korba BE, Cote PJ, Gerin JL. Animal models in the preclinical assessment of therapy for viral hepatitis. Antiviral Ther 1996;1:47-52.

44. Korba BE, Cote P, Hornbuckle W, Tennant BC, Gerin JL. Treatment of chronic woodchuck hepatitis virus infection in the Eastern woodchuck (Marmota monax) with nucleoside analogues is predictive of therapy for chronic hepatitis B virus infection in humans. Hepatology 2000;31:1165-1175.

45. Gerin JL, Korba BE, Cote PJ, Tennant BC. A preliminary report of a controlled study of thymosin alpha-1 in the woodchuck model of hepadnavirus infection. Adv Exp Med Biol 1992;312:121-123.

46. Gangemi JD, Korba B, Tennant B, Ueda H, Jay G. Antiviral and anti-proliferative activities of $\alpha$ interferons in experimental hepatitis B virus infections. Antiviral Ther 1996;1:64-70.

47. Korba BE, Gerin JL. Use of a standardized cell culture assay to assess activities of nucleoside analogs against hepatitis $B$ virus replication. Antiviral Res 1992;19:55-70.

48. Tennant BC, Baldwin BH, Graham LA, Ascenzi MA, Hornbuckle WE, Rowland PH, Tochkov IA, Yeager AE, Erb HN, Colacino JM, Lopez C, Engelhardt JA, Bowsher RR, Richardson FC, Lewis W, Cote PJ, Korba BE, Gerin JL. Antiviral activity and toxicity of fialuridine in the woodchuck model of hepatitis B virus infection. Hepatology 1998;28:179-191.

49. Rajagopalan P, Boudinot FD, Chu CK, Tennant BC, Baldwin BH, Schinazi RF. Pharmacokinetics of (-)-2'-3'-dideoxy-3'thiacytidine in woodchucks. Antimicrob Agents Chemother 1996;40:642645.

50. Mason WS, Cullen J, Moraleda G, Saputelli J, Aldrich CE, Miller DS, Tennant B, Frick L, Averett D, Condreay LD, Jilbert AR. Lamivudine therapy of WHV-infected woodchucks. Virology 1998; 245:18-32.

51. Korba BE, Cote P, Hornbuckle W, Schinazi R, Gangemi JD, Tennant $\mathrm{BC}$, Gerin JL. Enhanced antiviral benefit of combination therapy with lamivudine and alpha interferon against WHV replication in chronic carrier woodchucks. Antiviral Ther 2000;5:95-104.

52. Moraleda G, Saputelli J, Aldrich CE, Averett D, Condreay L, Mason WS. Lack of effect of antiviral therapy in nondividing hepatocyte cultures on the closed circular DNA of woodchuck hepatitis virus. J Virol 1997;71:9392-9399.

53. Peek SF, Tochkov, IA, Erb HN, Schinazi RF, Korba BE, Cote PJ, Gerin JL, Tennant BC. 3'-thiacytidine (3TC) delays development of hepatocellular carcinoma (HCC) in woodchucks with experimentally induced chronic woodchuck hepatitis virus (WHV) infection. Preliminary results of a lifetime study. Hepatology 1997;26: 368A.

54. Zhou T, Saputelli J, Aldrich CE, Deslauriers M, Condreay LD, Mason WS. Emergence of drug-resistant populations of woodchuck hepatitis virus in woodchucks treated with the antiviral nucleoside lamivudine. Antimicrob Agents Chemother 1999;43: 1947-1954.
55. Tatti KM, Korba BE, Stang HL, Peek S, Gerin JL, Tennant BC, Schinazi RF. Mutations in the conserved woodchuck hepatitis virus polymerase FLLA and YMDD regions conferring resistance to lamivudine. Antiviral Res 2002;55:141-150.

56. Lau DT, Khokhar MF, Doo E, Ghany MG, Herion D, Park Y, Kleiner DE, Schmid P, Condreay LD, Gauthier J, Kuhns MC, Liang TJ, Hoofnagle JH. Long-term therapy of chronic hepatitis B with lamivudine. Hepatology 2000;32:828-834.

57. Lok AS, Hussain M, Cursano C, Margotti M, Gramenzi A, Grazi GL, Jovine $\mathrm{E}$, Benardi M, Andreone P. Evolution of hepatitis B virus polymerase gene mutations in hepatitis $B$ e antigen-negative patients receiving lamivudine therapy. Hepatology 2000;32:11451153.

58. Liu X, Schinazi RF. Hepatitis B virus resistance to lamivudine and its clinical implications. Antiviral Chem Chemother 2002;13:143-155.

59. Jacob JR, Korba BE, Cote PJ, Toshkov I, Delaney WE, Gerin JL, Tennant BC. Suppression of lamivudine-resistant B-domain mutants by adefovir dipivoxil in the woodchuck hepatitis virus model. Antiviral Res 2004;63:115-121.

60. Korba BE, Cote P, Hornbuckle W, Schinazi R, Gerin JL, Tennant BC. Enhanced antiviral benefit of combination therapy with lamivudine and famciclovir against WHV replication in chronic WHV carrier woodchucks. Antiviral Res 2000;45:19-32. Corrigendum: Antiviral Res 2000;45:155-156.

61. Enriquez PM, Jung C, Josephson L, Tennant BC. Conjugation of adenine arabinoside $5^{\prime}$-monophosphate to arabinogalactan: synthesis, characterization, and antiviral activity. Bioconjug Chem 1995;6:195-202.

62. Hostetler KY, Beadle JR, Hornbuckle WE, Bellezza CA, Tochkov IA, Cote PJ, Gerin JL, Korba BE, Tennant BC. Antiviral activities of oral 1-0-hexadecylpropanediol-3-phosphoacyclovir and acyclovir in woodchucks with chronic woodchuck hepatitis virus infection. Antimicrob Agents Chemother 2000;44:1964-1969.

63. Korba BE, Schinazi RF, Cote P, Tennant BC, Gerin JL. Effect of oral administration of emtricitabine on woodchuck hepatitis virus replication in chronically infected woodchucks. Antimicrob Agents Chemother 2000;44:1757-1760.

64. Peek SF, Cote PJ, Jacob JR, Toshkov IA, Hornbuckle WE, Baldwin BH, Wells FV, Chu CK, Gerin JL, Tennant BC, Korba BE. Antiviral activity of clevudine [L-FMAU, (1-(2-fluoro-5-methyl-beta, L-arabinofuranosyl) uracil)]against woodchuck hepatitis virus replication and gene expression in chronically infected woodchucks (Marmota monax). Hepatology 2001;33:254-266.

65. Genovesi EV, Lamb L, Medina I, Taylor D, Seifer M, Innaimo S, Colonno RJ, Standring DN, Clark JM. Efficacy of the carbocyclic 2'-deoxyguanosine nucleoside BMS-200475 in the woodchuck model of hepatitis B virus infection. Antimicrob Agents Chemother 1998;42:3209-3217.

66. Colonno RJ, Genovesi EV, Medina I, Lamb L, Durham SK, Huang ML, Corey L, Littlejohn M, Locarnini S, Tennant BC, Rose B, Clark $J M$. Long-term entecavir treatment results in sustained antiviral efficacy and prolonged life span in the woodchuck model of chronic hepatitis infection. J Infect Dis 2001;184:1236-1245.

67. Bryant ML, Bridges EG, Placidi L, Faraj A, Loi AG, Pierra C, Dukhan D, Gosselin G, Imbach JL, Hernandez B, Juodawlkis A, Tennant B, Korba B, Cote P, Marion P, Cretton-Scott E, Schinazi RF, Sommadossi JP. Antiviral L-nucleosides specific for hepatitis B virus infection. Antimicrob Agents Chemother 2001;45:229-235.

68. Standring DN, Bridges EG, Placidi L, Faraj A, Loi AG, Pierra C, Dukhan D, Gosselin G, Imbach JL, Hernandez B, Juodawlkis A, Tennant B, Korba B, Cote P, Cretton-Scott E, Schinazi RF, Myers M, Bryant ML, Sommadossi JP. Antiviral beta-L-nucleosides specific for hepatitis B virus infection. Antiviral Chem Chemother 2001;12:119-129.

69. Menne S, Roneker CA, Korba BE, Gerin JL, Tennant BC, Cote PJ. Immunization with surface antigen vaccine alone and after treatment with 1-(2-fluoro-5-methyl-beta-L-arabinofuranosyl)-uracil (L- 
FMAU) breaks humoral and cell-mediated immune tolerance in chronic woodchuck hepatitis virus infection. J Virol 2002; 76:5305-5314.

70. Liaw Y-F, Sung JJY, Chow WC, Shue K, Keene O, Farrell G. Effects of lamivudine on disease progression and development of liver cancer in advanced chronic hepatitis B: a prospective double blind placebo-controlled clinical trial. Hepatology 2003;28: 262A(abstr).

71. Shiga J, Ohnishi S, Imawari M, Yamamoto K, Koshimizu K, Sasaki N. Development and growth pattern of small hepatocellular carcinomas in woodchucks-analysis of an animal model of human hepatocellular carcinoma by ultrasonography. Jikken Dobutsu 1991;40:545-548.

72. Gouillat C, Manganas D, Zoulim F, Vitrey D, Saguier G, Guillaud M, Ain JF, Duque-Campos R, Jamard C, Praves M, Trepo C. Woodchuck hepatitis virus-induced carcinoma as a relevant natural model for therapy of human hepatoma. J Hepatol 1997;26: $1324-1330$.

73. Lisi D, Kondili LA, Ramieri MT, Giuseppetti R, Bruni R, Della Rocca C, De Santis A, Rapicetta M. Ultrasonography in the study of hepatocellular carcinoma in woodchucks chronically infected with WHV. Lab Anim 2003;37:233-240.

74. Goldberg BB, Liu JB, Burns PN, Merton DA, Forsberg F. Galactose-based intravenous sonographic contrast agent: experimental studies. J Ultrasound Med 1993;12:463-470.

75. Forsberg F, Liu JB, Merton DA, Rawool NM, Goldberg BB. Parenchymal enhancement and tumor visualization using a new sonographic contrast agent. J Ultrasound Med 1995;14:949-957.

76. Forsberg F, Goldberg BB, Liu JB, Merton DA, Rawool NM. On the feasibility of real-time, in vivo harmonic imaging with proteinaceous microspheres. J Ultrasound Med 1996;15:853-860.

77. Kono Y, Moriyasu F, Nada T, Suginoshita Y, Matsumura T, Kobayashi K, Nakamura T, Chiba T. Gray scale second harmonic imaging of the liver: a preliminary animal study. Ultrasound Med Biol 1997;23:719-726.
78. Forsberg F, Roy R, Merton DA, Rawool NM, Liu JB, Huang M, Kessler D, Goldberg BB. Conventional and hypobaric activation of an ultrasound contrast agent. Ultrasound Med Biol 1998;24: 1143-1150.

79. Nada T, Moriyasu F, Kono Y, Suginoshita Y, Matsumura T, Kobayashi K, Nakamura T, Chiba T. Sonographic detection of tumor blood flow using a new contrast agent in woodchuck hepatomas. J Ultrasound Med 1997;16:485-491.

80. Forsberg F, Goldberg BB, Liu JB, Merton DA, Rawool NM, Shi WT. Tissue-specific US contrast agent for evaluation of hepatic and splenic parenchyma. Radiology 1999;210:125-132.

81. Ohtomo K, Shiga J, Sasaki Y, Itai Y. [Iron oxide-enhanced MR imaging of hepatocellular carcinoma of woodchuck]. Nippon Igaku Hoshasen Gakkai Zasshi 1991;51:433-435.

82. Reimer P, Weissleder R, Brady TJ, Yeager AE, Baldwin BH, Tennant $\mathrm{BC}$, Wittenberg J. Experimental hepatocellular carcinoma: MR receptor imaging. Radiology 1991;180:641-645.

83. Bilbao R, Gerolami R, Bralet MP, Qian C, Tran PL, Tennant B, Prieto J, Brechot C. Transduction efficacy, antitumoral effect, and toxicity of adenovirus-mediated herpes simplex virus thymidine kinase/ganciclovir therapy of hepatocellular carcinoma: the woodchuck animal model. Cancer Gene Ther 2000;7:657-662.

84. Putzer BM, Stiewe T, Rodicker F, Schildgen O, Ruhm S, Dirsch O, Fiedler M, Damen U, Tennant B, Scherer C, Graham FL, Roggendorf M. Large nontransplanted hepatocellular carcinoma in woodchucks: treatment with adenovirus-mediated delivery of interleukin 12/B7.1 genes. J Natl Cancer Inst 2001;93:472-479.

Address requests for reprints to: Bud C. Tennant, DVM, Gastrointestinal Unit, Department of Clinical Sciences, College of Veterinary Medicine, Cornell University, Ithaca, NY 14953. e-mail: bct3@cornell.edu; fax: (607) 253-3289.

Supported in part by contracts from the National Institute of Allergy and Infectious Diseases to Cornell University (N01-Al-05399) and Georgetown University (N01-Al-95390). 